[DOI: 10.24214/jecet.A.8.1.12331]

Juurnal of Enviranmental Science, Computer Science and Engineering \& Technology

An International Peer Review E-3 Journal of Sciences and Technology

Available online at www.jecet.org

Section A: Environmental Science

Research Article

\title{
Waste to Wealth: Comparative Production Of Adhesives From Fish, Goat And Cow Bones
}

\author{
${ }^{1}$ Ibrahim I. L., ${ }^{2}$ Musah, M. ${ }^{1}$ Umar, M. T. ${ }^{1}$ Dagaci,M. Z. ${ }^{1}$ Paiko, Y. B. and ${ }^{3}$ Salawu, F. B. \\ ${ }^{1}$ Department of Chemistry, Ibrahim Badamasi Babangida University Lapai, Niger State, Nigeria. \\ ${ }^{2}$ Department of Chemistry, Niger State College of Education, P M. B. 39, Minna, Nigeria. \\ ${ }^{3}$ Department of Mathematics and Lab Science, Chemistry Unit, Federal Polytechnic Bida, Niger \\ State, Nigeria.
}

Received: 01 February 2019; Revised: 14 February 2019; Accepted: 21 February 2019

\begin{abstract}
This project involves preparation of Adhesives from cow, fish and goat bones. The qualities of the samples were compared with the aim of picking which of the waste bones gave better product and in addition serve as generating sources of income more. The $\mathrm{pH}$, refractive index, conductivity, solid content, density and Bond Strength of these products were carried out. Plastic, ply-wood and glass were used to determine the Bond Strength. Cow samples gave Bond Strength with ply wood between glasses, and plastic on the range 37.49-68.25 N/m², 51.79-68.02 N/m $/ \mathrm{m}^{2}$ and 10.26$18.80 \mathrm{~N} / \mathrm{m}^{2}$ respectively, Fish samples gave Bond Strength with plywood between glasses and plastic as $33.85-25.64 \mathrm{~N} / \mathrm{m}^{2}, 25.64-82.15 \mathrm{~N} / \mathrm{m}^{2}$ and $12.82-12.52 \mathrm{~N} / \mathrm{m}^{2 \mathrm{r}}$ respectively. Goat samples Bond Strength with plywood between glasses and plastics $33.33-25.64 \mathrm{~N} / \mathrm{m}^{2}, 52.36-96.50 \mathrm{~N} / \mathrm{m}^{2}$ and $8.55-10.26 \mathrm{~N} / \mathrm{m}^{2}$ respectively. The result from this study indicated that samples from cow bones gave the best adhesives followed by samples from fish bones and that of goat and on the overall result if vision 2025 of United Nations is to be achieved by the new transformation agenda coupled with diversification of our economy, then small scale factories could be an answer by establishment to produce adhesives from waste materials like bones.
\end{abstract}

Keywords: Bones, Fish, Goat, Cow, and Adhesives 


\section{INTRODUCTION}

Adhesives are organic colloidal substances of varying appearance, chemical composition and physical properties. It couldoccur in commercial wide variety of forms and colors. The colors range from all shades of white, yellow, brown, transparent, translucent and opaque. Gelatin or glue-forming tissues occur in the bones, skins and intestines of all animals. These agglutinating materials are extracted with hot water, and the solution, on evaporation and cooling, yields a jelly-like substance gelatin or glue. Glue could also be prepared from fish bones, skins or bladders ${ }^{1.2}$. Animal glue was one of the first adhesives used with the basic adhesive substance of glue obtained from the hydrolysis of collagen the protein substance contained in the tissues of living organisms ${ }^{3,4}$. Collagen is an insoluble fibrous protein that occurs in vertebrates as the primary constituent of connective tissue fibre and in bones and yields gelatin and glue with pro-longed heating with water ${ }^{5-7}$. Glue largely consists of gelatin, but the collagen from which gelatin is prepared is invariably associated with other protein material such as keratin, elastin, mucin, chondrin ${ }^{1,2,5}$.The aim of this paper is at the instance of serious concern in the rate of increase in generation of animal and fish bone wastes and importation of almost every item seen in global markets which call for reappraisal of way manner in which we conduct our lives and see possibilities of the establishment of cottage industry with simple technology of converting these waste materials to useful substances call glues and adhesives ${ }^{8-11 .}$

\section{MATERIAL AND METHOD}

Sample Preparation Skinning and Sizing: The Fish,Cow and Goat waste sample bones were collected and all the flesh around them were removed and the size were reduced, the tilapia fish was bought and soak for some time to remove the flesh and bone. The bone samples were washed with large volume of water and detergent solution until all the contaminant such as food, dirt, meat particles and impurities were totally removed, the washed bones were then soaked in benzene for three day (72hours). This is to remove the fat content left on the of the bone. The bones samples were drained and allow to dry naturally under room temperature; the goat bone that has high fat content was dried in the oven at about $50^{\circ} \mathrm{C}$ for 2 hours. The dried bones samples were properly milled into powder, sieved into very fine particles, and packed in a polythene bags and were labeled ${ }^{1-4,12-14}$.

Table 1: Formulation of the Adhesives for Cow, Fish and Goat bones

\begin{tabular}{|c|c|c|}
\hline S/No & Components & Quantity \\
\hline 1 & Bone powder & $100 \mathrm{~g}$ \\
\hline $\mathbf{2}$ & Potassium hydroxide solution & $150 \mathrm{~cm}^{3}$ \\
\hline $\mathbf{3}$ & Natrosol (hydroxyl ethyl cellulose) & Paste (little) \\
\hline 4 & Sodium laureth (sufate) N 70 gel & $2 \mathrm{~g}$ \\
\hline 5 & Paraffin oil & $1 \mathrm{~cm}^{3}$ \\
\hline 6 & Glycerol & $1 \mathrm{~cm}^{3}$ \\
\hline $\mathbf{7}$ & Sulphur & $1 \mathrm{~g}$ \\
\hline 8 & Calcium carbonate & $1 \mathrm{~g}$ \\
\hline 9 & Phenol & $1 \mathrm{~cm}^{3}$ \\
\hline 10 & Sodium benzoate & $1 \mathrm{~cm}^{3}$ \\
\hline
\end{tabular}

Function of each components in the adhesive: $\mathrm{KOH}$ solution stabilizes and prevents the adhesive resins from coagulation on storage. Tescapon $\mathrm{N} 70$ gel serves as a surface active agent, and promoting 
wettability and lower surface tension. Natrosol this is a thickener, thus control viscosity. Paraffin oil is a plasticizer which controls flexibility and cohesive strength. Sulphur powder is a curing agent and cross link the polymer chains with that of the substrates. $\mathrm{CaCO}_{3}$ powder this acts as a filler, it brings about stiffness of the adhesive. Phenol is an antioxidant, it help in retarding degradation by sunlight and heat. Sodium benzoate act as a preservative, help in preventing microbial contamination on storage

Solid Content Determination; Weigh a dry crucible and record the weight as $\mathrm{W}_{0}$, on the same crucible without adjustment. Add the sample and record the weight of sample and crucible as $\mathrm{W}_{1}$.Transfer to a desiccator and take to the oven, carefully put in to dry at $105^{\circ} \mathrm{C}$ for 1 hour. Remove with thongs and reput in the desiccators and allow to cool.Re -weigh and record the new weight as $\mathrm{W}_{2}$ and calculate moisture content in percentage ${ }^{3,4,12-14}$.

Calculation:-

$$
\% \text { Solid Content }=\frac{W_{1}-W_{2}}{W_{1}-W_{0}}
$$

Where:- $\quad \mathrm{W}_{0}=$ weight of crucible

$\mathrm{W}_{1}=$ weight of crucible and sample

$\mathrm{W}_{2}=$ Weight after heat treatment

Determination of Refractive index: The cover plate was opened, surface of the prism cleaned with a cotton wool, Refractometer was standardize using distilled water, sample was dropped in the cover plate, covered by slightly pressing. Then corresponding scale of light and dark boundary taken, using the eye piece under a bright light or in the sunlight. The reading is the brix of the measured sample.

Determination of conductivity: The meter was switch on, rinsed and cleansed, it was then deep into the samples and readings were recorded.

Determination of $\mathbf{p H}$ values: The $\mathrm{pH}$ meter was standardized by immersing the electrode in a buffer of $\mathrm{pH} 4$ and $\mathrm{pH} 9$ and the meter adjusted, the electrode was deep into the samples and reading recorded.

Determination of Density: This was done by measuring a particular volume and taking the weight of that volume, and calculated as shown below.

Density $=$ mass or weight $/$ volume .

Determination of Viscosity: The viscometer was cleaned and fix to power sources to make sure is working properly, the pointer must be at zero before taking measurements. The sample to be measured poured into a beaker of diameter not less than $70 \mathrm{~mm}$. Screw the appropriate rotator into the connecting screw. The rotator immersed into the sample gradually until the water level symbol on the rotator is at the same height with the liquid surface, turn on the electromotor switch. Allow the pin to rotate for 2030seconds, then push the indicator controlling pole to make the value fixed ${ }^{3,411-14}$.

Determination of Bond Strength: This was done by falling weight method, varying weight loaded on a side of the joint material until the load pull the glued substrate apart, the weight that pull re substrate recorded and the surface area of contact is used in calculating the (acrid strength as shown below.

$$
\text { Bond Strength }=\frac{\operatorname{Load}(N)}{\text { Area of contact }\left(\mathrm{m}^{2}\right)}
$$




\section{RESULT AND DISCUSSION}

Results: Adhesives of bones of cow, fish and goat was formulated, the analyses ( $p H$, moisture content, refractive index, viscosity density, conductivity and bond strength), the results obtain were show in the tables below:

Table 2: Solid content in percentage

\begin{tabular}{|c|c|c|c|}
\hline S/No & Cow bone & Fish bone & Goat bone \\
\hline 1 & 45.71 & 66.67 & 63.63 \\
\hline 2 & 45.69 & 66.65 & 63.32 \\
\hline 3 & 45.70 & 66.66 & 63.30 \\
\hline 4 & 45.68 & 66.68 & 63.31 \\
\hline 5 & 45.72 & 66.69 & 63.34 \\
\hline 6 & 45.73 & 66.64 & 63.35 \\
\hline 7 & 45.70 & 66.67 & 63.36 \\
\hline
\end{tabular}

Table 3: Refractive index

\begin{tabular}{cccc}
\hline S/NO & Cow bone & Fish bone & Goat bone \\
\hline 1 & 3.85 & 1.10 & 1.80 \\
2 & 0.85 & 1.05 & 1.85 \\
3 & 0.95 & 1.00 & 1.83 \\
4 & 0.90 & 1.00 & 1.83 \\
5 & 0.87 & 1.00 & 1.82 \\
6 & 0.85 & 1.00 & 1.82 \\
7 & 0.85 & 1.00 & 1.82 \\
\hline
\end{tabular}

Table 4: Conductivity in $\mu \mathrm{scm}^{-1}$

\begin{tabular}{|l|c|c|c|}
\hline S/No & Cow bone & Fish bone & Goat bone \\
\hline 1 & 165 & 160 & 172 \\
\hline 2 & 168 & 160 & 172 \\
\hline 3 & 165 & 162 & 175 \\
\hline 4 & 168 & 163 & 172 \\
\hline 5 & 165 & 160 & 174 \\
\hline 6 & 165 & 10 & 172 \\
\hline 7 & 168 & 163 & 172 \\
\hline
\end{tabular}

Table 5: $\mathrm{pH}$ - Value

\begin{tabular}{|c|c|c|c|}
\hline S/No & Cow bone & Fish bone & Goat bone \\
\hline 1 & 9.90 & 8.65 & 8.63 \\
\hline 2 & 9.32 & 8.70 & 8.86 \\
\hline 3 & 8.95 & 8.71 & 8.92 \\
\hline 4 & 9.50 & 8.66 & 8.60 \\
\hline 5 & 9.31 & 8.78 & 8.62 \\
\hline 6 & 9.32 & 8.69 & 8.63 \\
\hline 7 & 9.10 & 8.70 & 8.60 \\
\hline
\end{tabular}


Table 6: Density in $\mathrm{g} / \mathrm{cm}^{3}$

\begin{tabular}{|l|l|l|l|}
\hline S/No & Cow bone & Fish bone & Goat bone \\
\hline 1 & 1.60 & 1.20 & 1.28 \\
\hline 2 & 1.60 & 1.20 & 1.28 \\
\hline 3 & 1.60 & 1.20 & 1.28 \\
\hline 4 & 1.60 & 1.20 & 1.28 \\
\hline 5 & 1.60 & 1.20 & 1.28 \\
\hline 6 & 1.60 & 1.20 & 1.28 \\
\hline 7 & 1.60 & 1.20 & 1.28 \\
\hline
\end{tabular}

Table 7: Viscosity using $6 \mathrm{Rpm}$ and $12 \mathrm{Rpm}$

\begin{tabular}{|l|l|l|l|}
\hline S/No & Cow bone & Fish bone & Goat bone \\
\hline 1 & $3.5-6.0$ & $18.5-20,0$ & $10.0-14.0$ \\
\hline 2 & $3.5-5.0$ & $18.5-20.0$ & $10.5-14.0$ \\
\hline 3 & $3.5-5.5$ & $18.0-20.5$ & $10.0-14.8$ \\
\hline 4 & $3.4-6.0$ & $18.0-20.0$ & $10.5-14-5$ \\
\hline 5 & $3.4-6.0$ & $18.5-20.5$ & $10.5-14.0$ \\
\hline 6 & $3.4-6.0$ & $18.5-20.0$ & $10.0-14.5$ \\
\hline 7 & $3.4-5.5$ & $18.5-20.0$ & $10.0-14.5$ \\
\hline
\end{tabular}

Bond strength of the adhesive, determined at different time after application

Table 8: At 2Weeks

\begin{tabular}{|l|c|c|c|}
\hline Adhesive & Cow Bone $\left(\mathbf{N m}^{-2}\right)$ & Fish Bone $\left(\mathbf{N m}^{-2}\right)$ & Goat bone $\left(\mathbf{N m}^{-2}\right)$ \\
\hline Plywood & 37.49 & 33.85 & 33.33 \\
\hline Glass & 51.79 & 25.64 & 52.36 \\
\hline Plastic & 10.26 & 12.82 & 8.55 \\
\hline
\end{tabular}

Table 9 : At 3 weeks

\begin{tabular}{|l|c|c|c|}
\hline Adhesive & Cow Bone $\left(\mathbf{N m}^{-2}\right)$ & Fish Bone $\left(\mathbf{N m}^{-2}\right)$ & Goat bone $\left(\mathbf{N m}^{-2}\right)$ \\
\hline Plywood & 45.52 & 35.56 & 35.38 \\
\hline Glass & 55.50 & 35.25 & 58.35 \\
\hline Plastic & 10.56 & 14.25 & 10.85 \\
\hline
\end{tabular}

Table 10: At 4Weeks

\begin{tabular}{|l|c|c|c|}
\hline Adhesive & Cow Bone $\left(\mathbf{N m}^{-2}\right)$ & Fish Bone $\left(\mathbf{N m}^{-2}\right)$ & Goat bone( $\left.\mathbf{N m}^{-2}\right)$ \\
\hline Plywood & 57.60 & 38.46 & 38.46 \\
\hline Glass & 65.25 & 68.97 & 64.10 \\
\hline Plastic & 10.24 & 14.53 & 12.82 \\
\hline
\end{tabular}


Table 11: At 5 Weeks

\begin{tabular}{|l|c|c|c|}
\hline Adhesive & Cow Bone $\left(\mathbf{N m}^{-2}\right)$ & Fish Bone $\left(\mathbf{N m}^{-2}\right)$ & Goat bone $\left(\mathbf{N m}^{-2}\right)$ \\
\hline Plywood & 65.25 & 38.05 & 42.05 \\
\hline Glass & 68.50 & 71.85 & 68.25 \\
\hline Plastic & 15.85 & 14.35 & 1025 \\
\hline
\end{tabular}

Table 12: At 6 Weeks

\begin{tabular}{|l|c|c|c|}
\hline Adhesive & Cow Bone $\left(\mathbf{N m}^{-2}\right)$ & Fish Bone $\left(\mathbf{N m}^{-2}\right)$ & Goat bone $\left(\mathbf{N m}^{-2}\right)$ \\
\hline Plywood & 68.25 & 25.64 & 25.64 \\
\hline Glass & 68.02 & 82.15 & 96.15 \\
\hline Plastic & 18.80 & 12.82 & 10.26 \\
\hline
\end{tabular}

Table 13: Summary of the physical parameters of the Adhesives formulated.

\begin{tabular}{|l|l|l|l|}
\hline properties & Cow Bone & Fish Bone & Goat Bone \\
\hline Solid Content $(\%)$ & 45.70 & 66.66 & 63.47 \\
\hline Conductivity ${ }^{\mu \text { SCrn-1 }}$ & 166.29 & 161.14 & 172.71 \\
\hline Density $\left(\mathbf{g} / \mathbf{c m}^{\mathbf{3}}\right)$ & 1.60 & 1.20 & 1.28 \\
\hline Refractive Index & 0.89 & 1.02 & 1.82 \\
\hline Viscosity $($ Mpa-s) & $3.4-5.7$ & $18.4-20.1$ & $10.3-14.3$ \\
\hline pH-Value & 9.34 & 8.69 & 8.68 \\
\hline
\end{tabular}

Table 14 : Summary and trend of the Bond Strength

\begin{tabular}{|c|c|c|c|}
\hline \multirow[t]{2}{*}{ Week } & \multicolumn{3}{|c|}{ Cow Bone } \\
\hline & Plywood $\left(\mathrm{Nm}^{\prime 2}\right)$ & Glass $\left(\mathrm{Nm}^{62}\right)$ & Plastic $\left(\mathrm{Nm}^{* 2}\right)$ \\
\hline 2 & 37.49 & 51.79 & 10.26 \\
\hline 3 & 42.52 & 55.50 & 10.56 \\
\hline 4 & 57.60 & 65.25 & 10.24 \\
\hline 5 & 65.25 & 68.50 & 15.85 \\
\hline 6 & 68.25 & 68.02 & 18.80 \\
\hline \multirow[t]{2}{*}{ Week } & \multicolumn{3}{|c|}{ Fish Bone } \\
\hline & Plywood $\left(\mathrm{Nm}^{\prime 2}\right)$ & Glass $\left(\mathrm{Nm}^{62}\right)$ & Plastic $\left(\mathrm{Nm}^{* 2}\right)$ \\
\hline 2 & 33.85 & 25.64 & 12.82 \\
\hline 3 & 35.56 & 35.25 & 14.25 \\
\hline 4 & 38.46 & 68.97 & 14.53 \\
\hline 5 & 38.08 & 71.85 & 14.55 \\
\hline 6 & 25.64 & 82.15 & 12.52 \\
\hline
\end{tabular}

128 JECET; December 2018- February 2019; Sec. A; Vol.8. No.I, 123-131.

DOI:10.24214/jecet.A.8.1.12331. 


\begin{tabular}{|l|c|c|c|}
\hline \multirow{2}{*}{ Week } & \multicolumn{3}{|c|}{ Goat Bone } \\
\cline { 2 - 4 } & Plywood $\left(\mathbf{N m}^{\mathbf{2}}\right)$ & Glass $\left(\mathbf{N m}^{\mathbf{2}}\right)$ & Plastic $\left(\mathbf{N m}^{* \mathbf{2}}\right)$ \\
\hline 2 & 33.33 & 52.36 & 8.55 \\
\hline 3 & 35.38 & 58.35 & 10.85 \\
\hline 4 & 38.46 & 64.10 & 12.82 \\
\hline 5 & 42.85 & 68.25 & 10.25 \\
\hline 6 & 25.64 & 96.15 & 10.26 \\
\hline
\end{tabular}

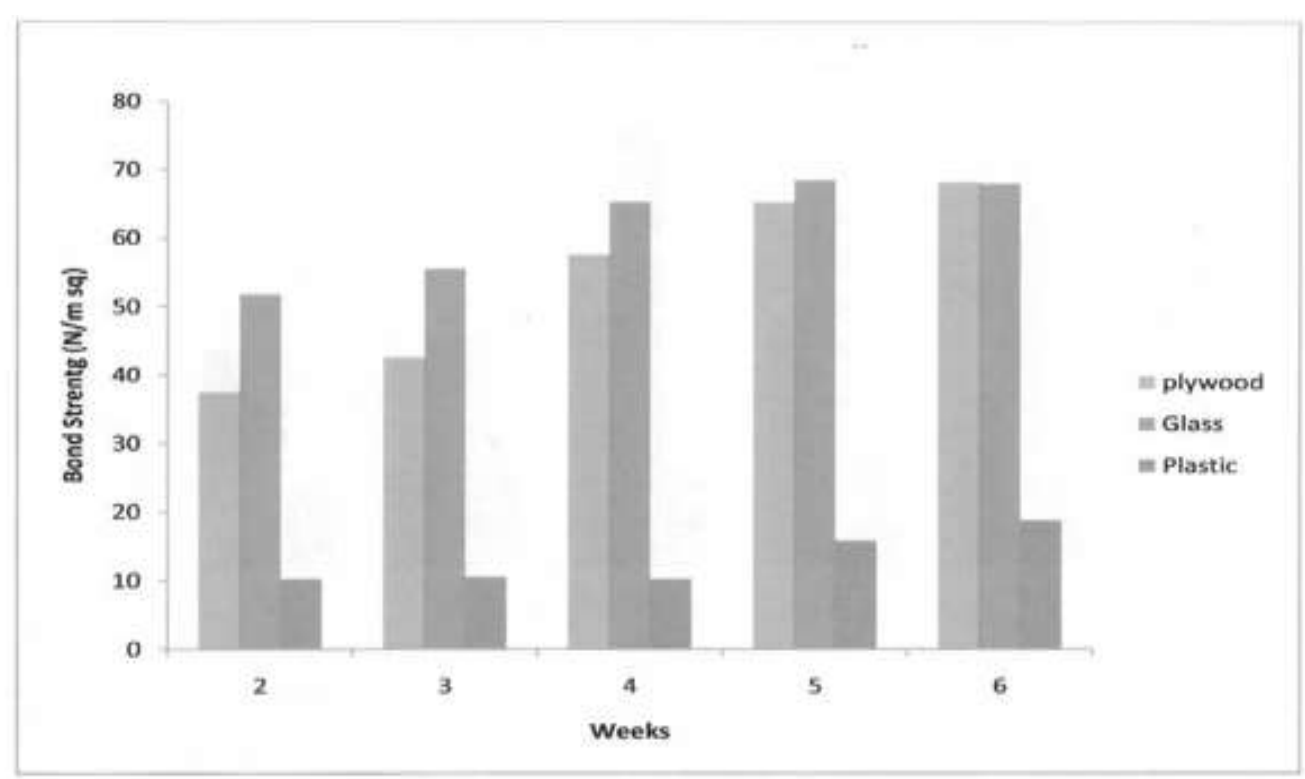

Fig.4.2: A chart showing the bond strength of adhesive of cow bone

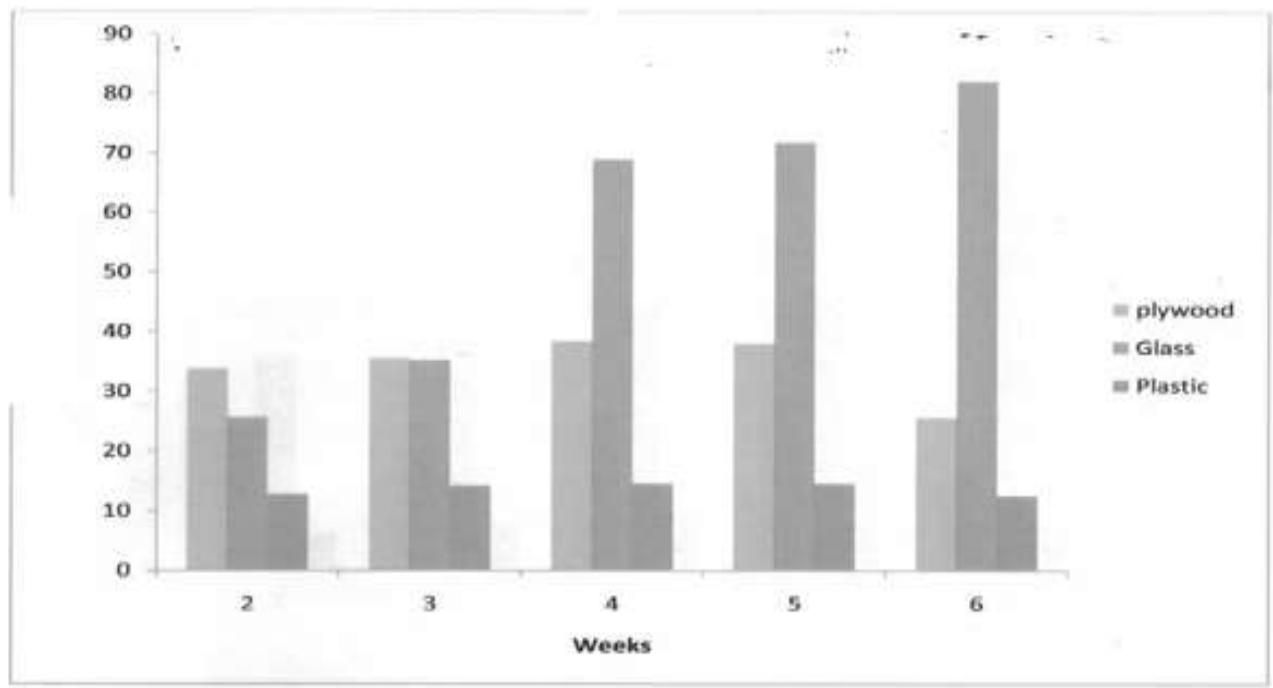

Fig.4.3: A chart showing the bond strength of adhesive of Fish bone 


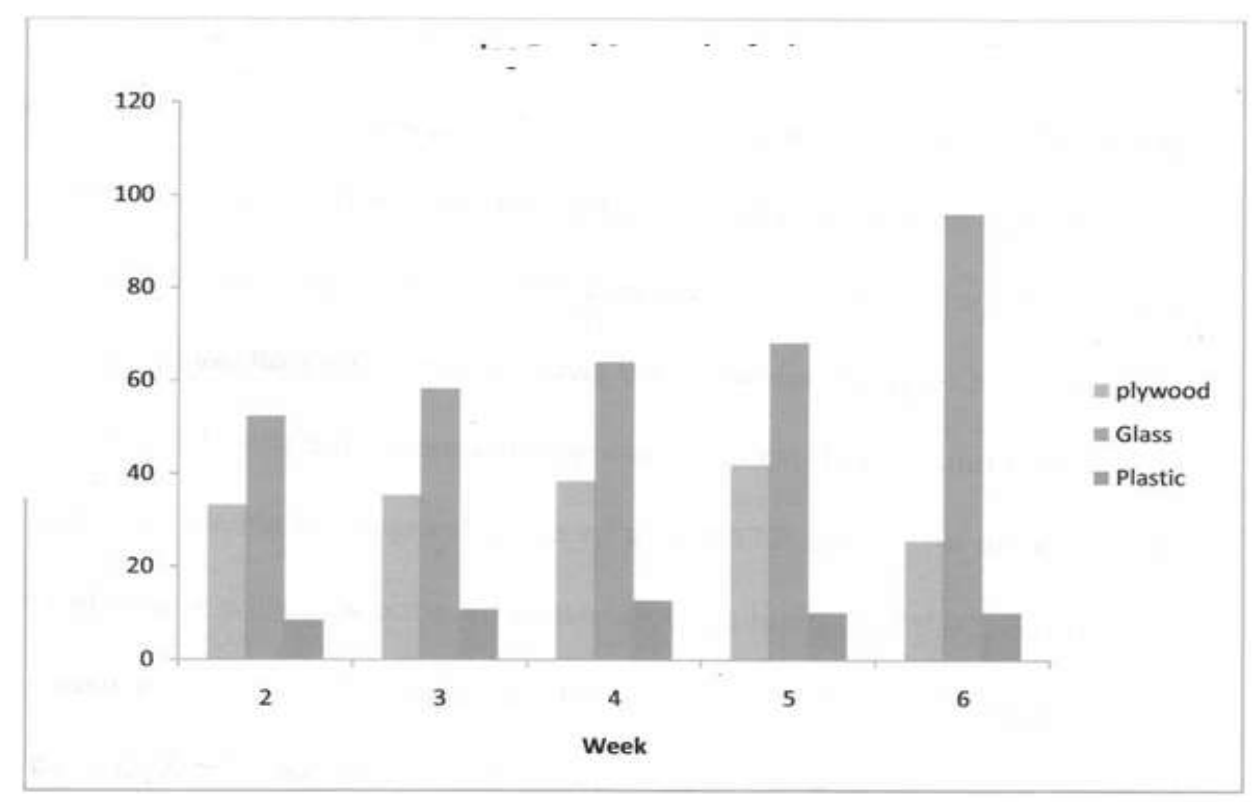

Fig.4.4: A chart showing the bond strength of adhesive of Gote bone

\section{DISCUSSION OF RESULT}

Adhesives from cow, fish and goat bone was produced and physical tests were done on them. The total solid content of the adhesives was done and found out that, they are all very high with the fish bone adhesive having the highest value of $66 \%$ and above. Refractive index shows the value for the goat bone adhesive been the highest with 1.85 . Conductivity was moderately high and that of goat bone adhesive having the highest value of about $172 \mathrm{ps} / \mathrm{cm}$. The $\mathrm{pH}$ values are alkaline in nature with cow bone adhesive with the highest of 9.90. Density was determined and the results show that the cow bone adhesive has the highest value of $1.60 \mathrm{~g} / \mathrm{cm}^{3}$. Viscosity was done with result showing fish bone adhesive with $18.5-20.5$ as the highest value.

Bond Strength was the major parameter of interest, being the quality that can determine the suitability of using animal bones as raw material for making adhesives. Bond Strength of the cow bone adhesive, using 3 different substrates; plywood, glass and plastic were found to between $37.49-68.23 \mathrm{~N} / \mathrm{m}^{2}, 51.79$ $68.02 \mathrm{~N} / \mathrm{m}^{2}$ and $10.26-18.80 \mathrm{~N} / \mathrm{m}^{2}$, respectively. Fish bone adhesive shows a Bond Strength on the following substrates; plywood, glass, and plastic to be between $33.39-25.64 \mathrm{~N} / \mathrm{m}^{2}, 25.64-82.15 \mathrm{~N} / \mathrm{m}^{2}$, and $12.82-12.52 \mathrm{~N} / \mathrm{m}^{2}$ respectively. While that goat bone adhesive shows Bond Strength between 33.33$25.64 \mathrm{~N} / \mathrm{m}^{2}, \quad 52.36-96.15 \mathrm{~N} / \mathrm{m}^{2} .8 .55-10.26 \mathrm{~N} / \mathrm{m}^{2}$, on the plywood, glass and plastic substrates respectively. These determinations were done within interval 2- 6weeks.

From table 4.13, cow bone adhesive shows a consistence in increase in bond strength on all the substrates used from week 2- week 6 , which make the cow bone adhesive the best for the 3 substrates used in this research. The fish bone adhesive does not show consistence in the Bond Strength, it was high from week 2 and get low at the $6^{\text {th }}$ week $\left(33.39-25.64 \mathrm{~N} / \mathrm{m}^{2}\right)$ of the determination for the plywood and plastic, but for the glass it show increasing through the weeks, $\left(25.64-82.15 \mathrm{~N} / \mathrm{m}^{2}\right)$.Goat bone adhesive does not show consistence in the Bond Strength, decreases through the weeks for plywood substrate, which is between $33.33-25.64 \mathrm{~N} / \mathrm{m}^{2}$, but for glass and plastic their Bond Strength were increasing through the weeks. For plastic substrate with all the adhesives formulated, shows a very low Bond Strength, there may be low or no bond formation between the plastic and the adhesives 


\section{CONCLUSION}

Within the limit of all experimental errors, it can be concluded that waste bones from animal can be converted to wealth- adhesives (glue) which would have otherwise fossilized in the soil, the result of which is land pollution. Cheap raw materials for standard adhesive can also be tapped locally instead of been formulated synthetically, thus reduces cost, hazards and permit ease of application. These formulated adhesives from animal bones have comparable bond strength and vast applicability to substrates both locally and industrially, thus adhesive manufacturer could tap from these rich products to better the lots of bonding without hammering with nail or welding.

\section{RECOMMENDATIONS}

Adhesives can be formulated from natural raw material like animal bones. It could be recommended that more research should be done on these adhesive to improve on their mechanical strength and other properties that will enhance its applications and services with material durability. People should be made to know that adhesives of high bond strength and pollution free can be made from animal bones instead of chalk making. Government should assist the large scale production of these adhesives by the local manufacturer through the millennium development goals (MDGs) and the skill acquisition programs to create more jobs by patronizing, and improving on the qualities of all classes' additives for their formulation

\section{REFERENCES}

1. W. Blair, \&, C. L. Person, Adhesive Age. New York: Academic Press Inc.1987.

2. O. Kirk, Encyclopaedia of Chemical Technology. New York: McGraw- Hill. 1978.

3. ASTM, American Society for Testing and Materials. International West Conshohocken PA 19428-2959, Section 11 water and environmental Technology, 2004, vol II 01.

4. American Public Health Association (APHA) American Water Works Association (AWWA) and Water Pollution Control Federation (WPCF), Standard methods for the examination of water and wastewater. Port city press Baltimore Maryland $16^{\text {th }}$ Ed. 41:41-164, 1995.

5. O. George, All about Glue. New York, Van Nostrand Reinhold, 2011.

6. D.A. Bender, a Dictionary of Food and Nutrition. New York: Oxford University press,2005

7. G. Christian, the Analytical Chemistry. New Delhi: John Wiley and Sons, 2007.

8. F. Debi, History of Adhesive. New York: Oxford University press, 2011.

9. B. Encyclopaedia, Viscosity. Chicago: Encyclopaedia Britannica,2010

10. B. Encyclopaedia, Adhesive. Chicago: Ultimate Reference Suite, 2013

11. F.Z. Hofmeister, Physiological Chemistry. New York: McGraw Hill,2010,

12. J. B. Hubbard, In Animal Glue. New York: Van Nostrand Reinhold, 2007.

13. M. Jerry. Advance Organic Chemistry, Reaction Mechanism and Structure. New York: Academic Press Inc, 1985

14. B. Mohammed, Production of Glue from Cow Bone. Unpublished Student Project, HND in Science Laboratory,Federal Polytechnic, Bida, Niger State, Nigeria,2012.

\section{* Corresponding AuthorIbrahim I. L}

Department of Chemistry, Ibrahim Badamasi Babangida University Lapai, Niger State, Nigeria. 